\title{
Innovation and Development of Commercial Banks in an Internet Finance Environment
}

\author{
Zhu Chen \\ School of Finance \\ Inner Mongolia Finance and Economics University \\ Hohhot 010070, China \\ chenzhusxy@126.com
}

\begin{abstract}
Through analysis of internet financial development models such as the third party payment model, the P2P lending model and the crowd funding model, the article discusses the impact of internet finance upon the commercial bank's place among payment agencies, its method of profit, traditional financing patterns and service models, and on the basis of the above, suggests innovative development methods such as an overall change of understanding of China's commercial banks in an Internet Finance Environment, accelerating the reserve and cultivation of talented personnel, developing client-centered service banks, constructing information-based banks by strengthening big data application, and continuous optimization of the bank's operation principle and management model. The investigation discussed in this article holds practical significance in promoting faster and better development of China's commercial banks under the environment of internet finance.
\end{abstract}

Keywords-internet finance; commercial bank; innovation; development

\section{INTRODUCTION}

Internet finance has promoted the development and innovation of every financial industry during its rapid development, and has made great growing space for the internet finance which connected both internet and finance. According to the report of the internationally known accounting firm PWC, banks and payment companies have already sensed the pressure coming from various kinds of financial technology companies. Money transfer companies and payment companies believe that in the upcoming five years they will lose up to $28 \%$ of businesses, which will all go to financial technology companies, while bankers believe that they themselves will lose $24 \%$ of businesses [1]. As the appearance and fast development of internet finance pushes Chinese finance industry towards diversity, it has also influenced and impacted various operating management activities in traditional commercial banks. Therefore, under such an environment, there is theoretical and practical significance towards the development of Chinese finance and economic progress to analyze the internet finance that is growing continuously.

\section{ANALYZING THE DEVElopMENT MODELS OF INTERNET FINANCE}

"Internet finance" mainly refers to the technology platform constructed between traditional financing institutions and internet enterprises for internet technology and information communications, a new financial model to achieve monetary circulation, payment problems, investment, and infomediary services. Currently, there are six primary development models of internet finance: third party payment, P2P, big data finance, crowd funding, informatization of financial institutions, internet financial portals; and newer models are continuously developed. For example on April 18, 2016, the fifth anniversary of the founding of Greenland Holding Group Company, the said company integrated online and offline resources of its subsidiary companies, fully integrating all branch companies using online platforms such as "Gkewang. com" and "Greenland Payment," involved all service abilities of subsidiary industries, and thus created a Greenland cloud platform. Another platform the "Finance Online" will also provide a professional, comprehensive, efficient and standardized one-stop financial investment service platform that offers investment product query, consultation, research, purchase and maintenance services. Therefore, in the future there will be a great diversity of internet financing models appearing in our economic life. Here, we will introduce three models that are most important and most classical [2].

\section{A. The third party payment model}

"Fig. 1" shows the transaction scale of Chinese third party payment operations, from year 2014 to the third quarter of year 2015. From "Fig. 1" we can clearly observe that the transaction scale of third party internet payment operations has been increasing year after year, and from its trend line surmise the broad prospects of its future development. 


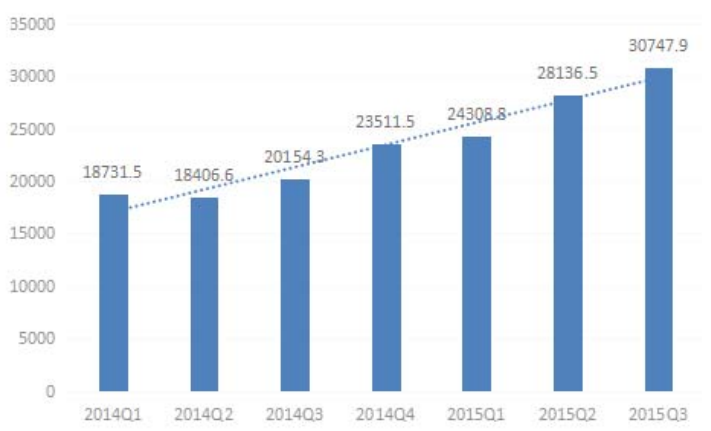

Fig. 1. The transaction scale of Chinese third party internet payment operations from 2014-2015Q3 (unit: 100 million yuan). Data source: iresearch.cn

\section{B. P2P lending model}

"Fig. 1" shows the transaction scale of Chinese third party payment operations, from year 2014 to the third quarter of year 2015. From "Fig. 1" we can clearly observe that the transaction scale of third party internet payment operations has been increasing year after year, and from its trend line surmise the broad prospects of its future development.

Year 2016 is the first year since internet finance had been listed into the 13th Five Year Plan, while being the first year after the publication of "Interim measures to P2P infomediary institution operations management." The P2P lending business is also growing towards a healthier prospect.

After the substantial growth of platforms in the previous two years, the number of P2P lending platforms shows laddering decrease in 2016. By the end of 2015 there were 2595 normally operating platforms in China, whereas by the end of June 2016 the number has decreased to 2349, reducing the number of normally operating platforms by 246 in 6 months as shown in fig. 2. According to estimation, the number of normally operating platforms is expected to undergo further reduction.

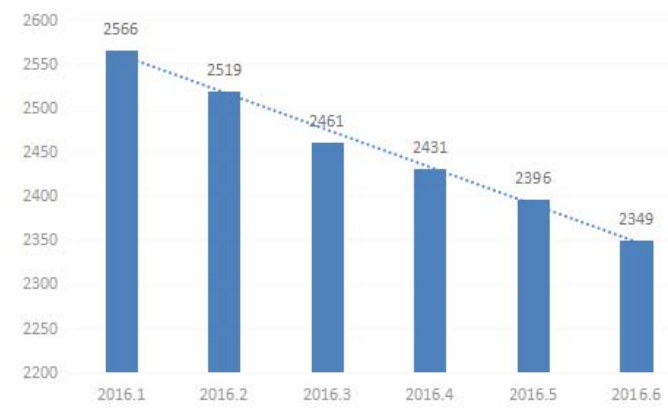

Fig. 2. The number of operating platforms per month in the first half of year 2016.Data source: 2016 Chinese P2P lending business semi-annual report

In the first half of year 2016, the proportion of the number of problem platforms versus the total number of terminated and problem platforms continue to decrease; in 2015 this value was approximately $60.38 \%$, and in 2016 it is already down to $44.68 \%$. This also means that the number of platforms that underwent benign exit has significantly increased. In the entire first half of year 2016, the total number of terminated or problem platforms accumulates to 515, among which there are 247 cases of benign exit (terminated or transformed) and 268 cases of malignant exit (runaways, deposit withdrawal difficulties, or economic investigator involvement).

In 2016 many capitals are hurrying to arrange their P2P lending businesses. According to incomplete statistics, by June 2016 there were already 88 platforms that have received venture capitals, 90 state-owned asset platforms, 82 platforms with a listed company background, and 16 platforms with a bank background.

By the end of June 2016, the total turnover of P2P lending businesses has reached up to 2.207506 trillion yuan; in the first half of the year the total turnover amounts to 842.285 billion yuan. Considering the current growth trend, the turnover of P2P lending businesses for the entire year of 2016 may exceed past 2 trillion yuan, and in the second half of year 2016 will achieve the third trillion yuan.

\section{Crowd funding model}

"Crowd funding" refers to public financing, commonly known to be a model which displays innovation to the public on behalf of an enterprise or individual through the internet, in order to win attention and support from the public and obtain fund as a result. According to incomplete statistics, by the end of December 2015 there are 354 crowd funding platforms throughout China, in which 303 crowd funding platforms are currently on normal operation. Since the birth of the first crowd funding platform "DemoHour" in 2011, up to the addition of 6 more in 2012 and 27 more in 2013, the growth rate of crowd funding platforms has been relatively slow; whereas in 2014, due to the outburst of internet concepts, the number of crowd funding platforms has increased significantly, adding 142 towards the count. In 2015 there were 125 more crowd funding platforms, showing a decrease in the launch rate of new crowd funding platforms. However, while new platforms are continuously launching, a number of old platforms have undergone termination due to unsuccessful operations. Up to December 2015 there have been 32 terminated crowd funding platforms, in which most have been platforms that have launched in 2014 (17 out of 32); and those with the highest probability of termination, summing up to $34.48 \%$, are the platforms established in 2013.

\section{THE INFLUENCE OF INTERNET FINANCE ON COMMERCIAL BANKS}

The rapid development of internet finance has brought forth both opportunity and challenge for commercial banks. Challenge mainly manifests itself in the following aspects:

\section{A. Challenge to the payment agency position of commercial banks}

Commercial banks are payment agencies that take part in financial activities such as deposit, loan, exchange and payment. The basic function of their operation is to carry out monetary circulation, implemented via creditor's rights and debt pay-offs to overcome individuals' discrepancy of time and division of space [3]. Arrival of the internet era breaks the former designated place and specified time and leaves less 
limitations for time and space, the result of this is a significant enhancement of its ability as a payment agency, impacting the once unshakable position of commercial banks in respect of payment intermediation [4].

\section{B. Challenge to the profit model of commercial banks}

The development of internet finance has a large impact upon the profit model of commercial banks. Internet finance mainly wins customers' satisfaction via providing to the client highly efficient and convenient financial services and raising the value added of the provided services, whereas for commercial banks, profit mainly comes from two aspects: margin interest, and income of intermediate businesses [5]. However, with the continuous advancement of China's marketable interest rate reform, the interest margin between deposits and loans of the entire market will undergo further reduction. This leads up to the rapid development of internet finance which bargains through negotiation, and its high efficiency and speed have attracted many former clients of commercial banks, causing a sharp reduction in the earnings of commercial banks and prompted the transformation of its profit model.

\section{Challenge to the traditional financing pattern and service model of commercial banks}

Under the model of internet finance, there is already a financing platform created on the internet which allows creditors to indicate on the platform the available amount to lend out, the interest rate and the planned loan period, and allows borrowers to search on the website for the amount they need and the suitable interest rate. Furthermore, one website can achieve various patterns of finance such as one-to-many and many-for-one, thus greatly improving the efficiency problem of financing. Evidently, for the traditional financing pattern of "seizing deposits with one hand, lending out with the other" in commercial banks, the simple procedure and fast, convenient transactions of internet finance has already caused an impact [6]. , the right of choice for various financial products and services is held mostly in the individual hands of the financial demander; compared to the traditional financial service model, this type of financing emphasizes more on the "people-oriented" concept, fulfilling the clients' individual needs and firsthand experiences. The appearance of such a service model will also significantly elevate client satisfaction and participation [7].

\section{INNOVATION AND DEVELOPMENT OF COMMERCIAL BANKS UNDER THE ENVIRONMENT OF INTERNET FINANCE}

As the impact from internet finance intensifies, internet finance is rapidly transforming traditional business models and forms of organization, influencing consumers' habits and payment methods; commercial banks are facing the challenge of innovation and transformation. In face of such changes, traditional commercial banks need introspective and progressive insight to cope with the change and achieve the innovative development of the internet era. Concretely, they can begin with the following four aspects:

\section{A. Get to know the change thoroughly, and quicken the reservation and training of able personnel}

The era is advancing, and personnel need to be constantly updated. Following the continuous transformations of commercial banks, not only should personnel familiar with the financial business be brought in, but also the most necessary personnel in favor of commercial bank development - the multi-skilled personnel who can utilize new technology. Therefore it is important to reinforce the cultivation and introduction of personnel, to create a skillful and comprehensively knowledgeable team to cope with the current financial situation [8].

\section{B. Develop service banks that are client-oriented}

Banks belong to the tertiary industry, also known as service-oriented industry; its development depends upon client needs, which is also an important pathway for transformation and upgrading of commercial banks: establishing a "clientoriented" strategic thinking, building the value of commercial banks upon the value revealed through their clients, delve deep for client needs and satisfy clients' every need and services. On one hand, banks should establish the inclusive financial thinking with regards to internet finance, develop public clients, and continuously launch new products to accommodate the financial needs of people with different backgrounds [9]. On the other hand, banks should form an one-stop integrated financial platform that is omnibearing, integrating various platforms and resources such as payment service providers, information service providers and e-commerce enterprises; thus providing to clients an omnibearing, comprehensive service which satisfies their diversified financial needs. Furthermore, banks can improve the participation and experience of clients using the internet platform and guided by the market, thereby obtaining clients' satisfaction and approval [10].

\section{Constructing information-oriented banks via constructing big data}

Data has become a significant characteristic of the information age; the interpretation and prediction of every existing social and economic phenomenon cannot occur without the exploration and analysis of big data. The idea of prompting the transformation and upgrading of commercial banks through big data aligns with the general trend of current economic and financial development; it breaks away from the traditional data model of random sampling, using internal data of the bank as basis to collect and explore large amounts of social data, and constructs a big data platform inside the bank. This allows the managerial decision-making model of banks to become data-oriented and information-oriented banks to come into being.

\section{Continuously optimize the operation principle and management mode of the bank}

Under the new situation where internet finance continues to advance, commercial banks face challenges not only from the outside environment but also from within. As channels of financial service constantly expand and the efficiency of financial service heightens, the problem which commercial banks must face is to accelerate the mobility of funds. Under 


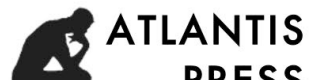 PRESS}

such a setting, the banking industry must respond with new operation principles and management modes: the first is to apply the technology of big data and elevate the level of delicacy management; the second is to introduce third party agencies and elevate the level of application and promotion; and the third is to make use of the "self-diffusing" ability of the internet to achieve client expansion, making clients become a significant driving force towards the promotion of commercial bank operations and the diffusion of the marketing brand.

\section{CONCLUSION}

As internet finance promotes the overall advancement of China's financial industry and accelerates its diversified development, it has also, to a certain degree, impacted the currently existing traditional operations of commercial banks, and hindered the further development of commercial banks. Although viewing from the current situation, the new internet banking system cannot yet cause a destructive blow upon the vast system of traditional banking, if the traditional banking industry seeks to break through and develop, they must grasp the opportunity in time and understand internet finance. Therefore, for commercial banks, whether it is their concepts of current operational management activities, business expansion methods, or their traditional business model, these aspects all need to undergo timely improvement, to elevate the vigor for innovation while improving the bank's own strengths. Furthermore, banks should learn from the advantageous status of internet finance, and make good use of this platform; they should embrace internet financing technologies, models, and the internet spirit of the present and the future. Commercial banks can apply the advantage of their own profession to achieve the strategic transformation of the "internet + " era, and then use this transformation to accelerate toward the goal of transforming China's commercial banks. Doing so will ensure the stable and constant improvement of the developmental level of Chinese commercial banks, and give a significant boost towards China's innovation and development in the financial field.

\section{REFERENCES}

[1] Hu, Shiliang, "Innovation and model of internet finance," Beijing: Posts \& Telecommunications Press, 2015, pp. 30-42.

[2] Wu, Zijie, Introduction to the research of the transformation of commercial banks under the internet finance environment, vol. 9. Science \& Technology Economy Market, 2015, pp. 44.

[3] Li, Haohao and Nan Zhou, Impact of internet finance upon commercial banks and countermeasures, vol. 10. Enterprise Economy, 2015, pp. 97100 .

[4] Shen, Mahui, Analysis of the impact of internet finance upon commercial banks, vol. 12. Market Modernization, 2016, pp. 105.

[5] $\mathrm{Mu}$, Lijie and Qiulian Chen, A path analysis of achieving a win-win between commercial banks and internet finance, vol. 3. International Finance, 2015, pp. 24-29.

[6] Zhou, Yan, Impact of internet finance upon the innovation of commercial banks, vol. 3. Economic Research Guide, 2014, pp. 101-102.

[7] Hong, Juan, Research of the competition strategy of commercial banks under the wave of internet finance, vol. 3. Finance Forum, 2014, pp. 810 .

[8] Li, Xin, Exploring the development of commercial banks under the environment of internet finance, vol. 8. Modern Business, 2015, pp. 144145.

[9] Li, Ying, Internet finance prompts transformation of the banking industry, vol. 3. The Banker, 2014, pp. 15-17.

[10] Lin, Xue, Research of the integration and development between internet finance and commercial bank operations, vol. 10. Finance Forum, 2014, pp. 21-28. 